\title{
(Dys)Function in the Moors: Everyone's a Villain in Wuthering Heights
}

\section{Samantha Przybylowicz}

Emily Brontë's classic Wuthering Heights combines legends, myths, and notions of romance, but it is also full of villains, dastardly acts, betrayal and revenge. Criticism of the work often centers around the characters of Heathcliff and Catherine $^{1}$ and their perceived feelings for one another, thwarted by fate, chance, and bad decisions. ${ }^{2}$ Many scholars point fingers at Heathcliff as being the ultimate "villain" of the story ${ }^{3}$; I, however, believe that the term "villain" is controversial, and this term can apply to all of the characters, not just Heathcliff-at least in the context of the world where the story takes place. In general, the villain can be a character who wishes evil things to happen and who helps to make these evil things happen. The villain may also be the dark side of human nature, the opposite of the hero, or what the hero could become if s/he ever fails. If we indeed have no heroes in Wuthering Heights, then the characters in the novel must all have a dark side (which may or may not be obvious), or be outright malicious in their intentions through their actions.

The novel has no "good" characters - even the Lintons, whom Nelly our narrator describes as virtuous, have cruel intentions as they are introduced fighting 
over a dog, and they repeatedly exhibit passive behaviors where action is called for. For the inhabitants of the moors, villainy is linked with identity, but the characters of Wuthering Heights tend to defy definition and boundaries. Villainy is ascribed to "otherness" and that which is not understood; because of misunderstandings and biased attitudes of most characters, readers form negative opinions and assume villainy before evil deeds are performed. Villainy in the novel therefore stems, at least in part, from social condemnation of certain characters early on in the novel.

Heathcliff often receives most of the criticism for being the most definitive villain in the novel; however, I believe he merely is placed in this position through the Nelly/Lockwood narration frame, which causes him to appear to exceed the villainy of other characters. ${ }^{4}$ Overall, I believe Heathcliff gets too much blame from critics for being devilish. In no way do I intend to excuse his behaviorsparticularly in the second half of the novel—nor do I have any romanticized notions of his heroism (as Isabella Linton does). What I fail to see, is how he is considered to be so much worse than many of the other characters of the novel to be examined here. Truly, after Catherine's death we see a desperate man: a man who goes so far as to throw a knife at his own wife and has disdain for all around him in the living world. Ingrid Geerken makes a claim in her article "'The Dead Are Not Annihilated': Mortal Regret in 'Wuthering Heights"” that Heathcliff is the only character to draw blood: "Only Heathcliff ever draws blood in the novel, and he does so in order to entice Catherine's shade to appear to him. These injuries constitute a sacrificial offering to the dead" (396). Here, Geerken even justifies his violence by ascribing a cause-and-effect thought process. If Heathcliff performs evil acts, he believes Catherine's ghost will appear. Why would Catherine be enticed by wicked behavior, unless she herself is inherently evil and villainous?

Also, there are several other instances in the novel where blood is drawn, which involve Catherine. One moment is when Lockwood is "dreaming" (as he believes he must have been) that Catherine is outside his window. He severs her wrist on the broken glass, and describes the blood spilling down the windowsill: "I pulled its wrist on to the broken pane, and rubbed it to and fro till the blood ran down and soaked the bed-clothes..." (25). Although only a dream and not real blood, the imagery in this passage is very strong and stays with the reader. Another instance of bloodshed is much simpler and easily goes by unnoticed; it is when Heathcliff has left the moors after Catherine has decided to marry Edgar and she falls into a delirium. Kenneth, the doctor, comes and "He bled her, and he told me to let her live on whey, and water gruel; and take care she did not throw herself down stairs, or out of the window...” (88). Although these two scenes manifest very different intentions in drawing blood, both factor into being able to control Catherine. Lockwood wants to control her by being able to keep her from 
entering her old room at Wuthering Heights, and the doctor wishes to help others control her fits of passion and keep her from killing herself. The theme of the drawing of blood throughout the novel represents repercussions of villainy, and the examples here show that Catherine is not exempt from being both villain and victim.

Critics and readers alike can easily ascribe the role of villain to Heathcliff because of his obvious outsider status in the novel. The language in the novel when Heathcliff is first brought home obviously commodifies him as an object and not as a human. He is frequently referred to with the pronoun "it" and the term "gipsy." The contemporary reputation for the term "gipsy" was dehumanizing and base, as we can see by the Lintons' reaction when meeting Heathcliff for the first time: "Frightful thing! Put him in the cellar, papa. He's exactly like the son of the fortune-teller, that stole my tame pheasant. Isn't he Edgar?” (50). Isabella's words indicate that Heathcliff gives a very negative first impression, particularly to the gentrified and refined world of Thrushcross Grange. She even suggests that he should be put in the cellar, as if he were an animal or prisoner, instead of being allowed in the house proper or any domestic/familial space. Furthermore, Heathcliff's otherness is emphasized by Nelly's narrative. He is raised as a fostersibling to the Earnshaw children - a place that Nelly obviously feels is her position. As Heathcliff moves in and becomes the foster-sibling in a more traditional manner, Nelly is pushed into the positions of servant, maid, and nurse, which may skew her perspective when recounting her tale.

Many of the characters, in fact, are pushed into roles that are not natural for them to occupy. Heathcliff becomes the replacement for a dead Earnshaw child; Nelly becomes mother-figure for Hareton and then Cathy (and explains her relationship to Hindley and Catherine as more motherly than sisterly). Geerken writes, “...Brontë challenges biology by privileging symbolic substitutions in her narrative....Catherine is closer to Heathcliff than to her natural brother, Hindley...Heathcliff supplants Hindley as Hareton's surrogate father. These symbolic substitutions generate possibilities that test the limits of social and moral propriety" (395). Another reason we view all of the characters as villainous is because they usurp roles in which they do not "naturally" belong. In addition to the association of "otherness" with villainy is the idea that a villain is an unnatural phenomenon in the natural world-particularly in the isolated natural world Brontë creates.

The Heathcliff-Hindley relationship is one catalyst causing Heathcliff to become a villain. As a child, Hindley is described as degrading and abusing Heathcliff on a regular basis, often because of Heathcliff's otherness and Hindley's sense of having been displaced by Heathcliff. The violence inflicted upon Heathcliff can be described as villainous; yet Hindley is not often blatantly described as being malevolent, especially early on in the novel. This is likely because he is not 
one of the characters in the central love triangle, and also perhaps because Nelly, our main narrator, has an affinity for him, as her “foster brother.” Despite Nelly's attachment to Hindley, she informs us that "The master's bad ways and bad companions formed a pretty example for Catherine and Heathcliff. His treatment of the latter was enough to make a fiend of a saint. And, truly, it appeared as if the lad were possessed of something diabolical at that period" (66). Later, she even tells a tale that paints Hindley in a truly evil light:
"But, with the help of Satan, I shall make you swallow the carving knife, Nelly! You needn’t laugh...I want to kill some of you, I shall have no rest till I do!” "But I don’t like the carv- ing knife, Mr. Hindley,” I answered; "it has been cutting red herrings - I'd rather be shot if you please.”... He held the knife in his hand, and pushed its point between my teeth: but, for my part, I was never much afraid of his vagaries. I spat out, and affirmed it tasted detestably-I would not take it on any account (74).

The threat here never results in physical injury, yet Hindley's tone and intentions are no better than Heathcliff's actions. Nelly's perspective causes a skewed dismissal of Hindley's aggression because her account deflects his threats and because of the sympathy she exhibits for him throughout the narrative. The reader, however, cannot dismiss Hindley's brutal actions, especially in light of how they contribute to shaping Heathcliff's nature.

Heathcliff's malevolent nature is often cited in one of their childhood altercations, where Heathcliff asks Hindley to change horses with him, as his fell lame and he wished to own the finer colt: "'You must exchange horses with me; I don't like mine, and if you won't I shall tell your father of the three thrashings you've given me this week, and show him my arm, which is black to the shoulder'” (39). Now, Heathcliff's attitude and demands here are not commendable, yet they are understandable as exemplary of young children who have faced the type of abuse and degradation that Heathcliff has obviously undergone from Hindley. Heathcliff here is starting to come into his own and is beginning to realize that he does not have to accept his forced lot in life, and we can hardly fault him for trying to improve his life and living situation, even if his request for Hindley's colt is selfish. Marianne Thormählen writes, "While the boy Heathcliff's wrongs at Hindley Earnshaw's hands at least foster a feeling that he is the victim of harshness and injustice, the growth of true sympathy for him is checked by several circumstances, such as his lack of discernible affection for his benefactor...the realization that Hindley has cause to be jealous... Heathcliff's blackmailing effort over the colts; and his intractable sullenness...” (184). I argue against Thormählen's claim that 
the reader's feelings for Heathcliff do not become true sympathy. We do sympathize with Heathcliff at this point because he cannot control his surroundings and does not yet know how to mitigate his outsider status, particularly since this status is the cause of hostility and accusation of villain from Hindley's perspective.

Heathcliff's early actions may be excused because of the degradation he has had to suffer, but can there be any excuse for his later regression? Brontë surely means to test our ideas of nature vs. nurture, as Heathcliff keeps pushing the limits. In fact, many of the character attacks in the novel center around Heathcliff; either he is condemning another character (Hindley, Edgar, Isabella, Linton...) or other characters are condemning him (Hindley from the moment Heathcliff is brought home; the Lintons when he is a mere child because of his inappropriate language; Nelly constantly through her pejorative descriptions). As soon as Heathcliff enters the Earnshaw household, he is denounced by the majority of its members: "Mrs. Earnshaw was ready to fling it out of doors;" Hindley shows more concern for his fiddle, which reduces him to tears when he finds it has been broken; and Catherine spits upon the gypsy boy at finding he is the cause of her lost whip (37). Even Nelly scorns the creature instead of taking care of him, which is part of her job for the Earnshaws; instead, she "put it on the landing of the stairs, hoping it might be gone on the morrow" (37). These character attacks are integral because they reiterate that there are no moral characters; nobody seems to be able to have any true regard for anyone else.

Only Mr. Earnshaw has any feelings toward Heathcliff early on, showing favoritism toward the stranger and keeping the others in line enough to prevent them from banishing the boy altogether. Heathcliff starts out life as unwanted, with the inhabitants of Wuthering Heights against him. His struggle throughout the novel to become something and to take revenge on Hindley and Edgar for thwarting him begins with this marginalization in his own household as being "other" and therefore not acceptable. Although Catherine soon warms up to Heathcliff and becomes closer to him than she is to her own brother, her cat-andmouse games constantly cycle through an accepted-unaccepted pattern for Heathcliff, and, from her perspective, Heathcliff seems more mercurial than clearly defined. In stark contrast, very few characters seem to condemn Catherine, with the exception of Nelly, who on more than one occasion states her displeasure and lack of love for the only Earnshaw daughter.

In the novel's opening chapters-the time before Lockwood asks Nelly to recount the history of the inhabitants of the Heights and the Grange-there is no particular reason to think Heathcliff a villain. The obtuse Lockwood makes his way into Wuthering Heights and this is how we first meet Heathcliff. Heathcliff is inhospitable as Lockwood experiences him, but at this point he is more of a mystery, and little of his character is revealed. Heathcliff appears very calm during the opening scenes; while he fails to save Mr. Lockwood from a canine mis- 
hap, he has had no active role in the attack which could reveal him as a villain. The back-and-forth layout of the novel causes us to return to the beginning as we approach the end, and it is then when we take these incidents as being indicative of Heathcliff's darker, more malevolent nature.

In fact, it is the young Cathy who causes us feelings of uneasiness based on her perceived wicked behavior in the opening scenes, not the brooding Heathcliff. Of course, Brontë will make us change our minds (at least a little) about Cathy by the end of the novel, but even Lockwood is incredulous that Nelly describes Cathy as a loving girl, when his experience in meeting her gave the opposite impression. Since we are easily convinced that Cathy is not what she seems, is it not possible that most of the characters are also not as they seem, particularly not as they appear to Lockwood's obtuse, outsider position. After all, while at the Heights, Lockwood hears Cathy speak to the ancient Joseph about her advancements in witchcraft: “...she continued, taking a long, dark book from a shelf. 'I'll show you have far I've progressed in the Black Art-I shall soon be competent to make a clear house of it. The red cow didn't die by chance; and your rheumatism can hardly be reckoned among providential visitations!'” (15). Joseph's reply is to call her "wicked," giving us a decidedly negative impression of the young beauty. Brontë challenges our idea of a villain by revealing evil intent in all characters at some point, even in pretty, young girls.

So why do we keep reading about villainous characters? I believe that on some level we do sympathize with most of the characters. We begin with some hope that things will work out between Catherine and Heathcliff. As we learn more about the characters, our sympathy diminishes, but as Thormählen observes, “...interest in a person is not dependent on sympathy for him or her, or Lockwood would never have asked the housekeeper at Thrushcross Grange to tell him 'the history of Mr. Heathcliff', and she could not have rendered such a detailed narrative, down to reproductions of lengthy conversations” (Thormählen 185). Our feelings of sympathy (if we have them) are not shared by the characters; none of them feel sympathy for one another and all of them have selfish motives.

Each character lies in his/her own isolated world and their feelings for each other are not always based on actions or empirical evidence. Cathy condemns Heathcliff by stating he cannot feel love, not knowing he has probably felt the deepest, truest love in the novel. She chooses to ignore the fact that reportedly her mother had loved Heathcliff. Nelly is the resident busybody, and even she has limits: she is not an omniscient narrator and cannot comment on Catherine's and Heathcliff's truest feelings or about their intimate moments out on the moors; nor does she understand their relationship. At an undetermined point, we as readers must establish the boundary between "reality" and fantasy for ourselves. It is one thing to be told Heathcliff is a villain and aligned with the devil, but one will invariably determine Heathcliff's wickedness due to his overabundance of manipu- 
lative actions. If Heathcliff has heard that he fulfills this role all his life, why would he not assume this identity?

While we see Cathy cannot sympathize with Heathcliff, Anne Williams points out that Catherine cannot sympathize with anyone: "She is incapable of sympathy; ironically her 'identification' with Heathcliff does not enable her to consider his feelings as in any way autonomous, as separate or different from her own” (Williams 119). Catherine appears to be much more destructive than she is often given credit for being, even if she is not aware of her capabilities, partially because of her inability to sympathize with anyone, particularly the man she claims is "more myself than I am" (81), and partially because of the hold she has over most of the characters, particularly the masculine Heathcliff and the weaker, slightly "emasculated" Edgar. In contrast to Heathcliff, most characters do not condemn Catherine, or if they do, their disapprobation is short lived. Heathcliff condemns her for a time after she chooses Edgar over himself, yet he returns from his mysterious adventure because of what we interpret to be a deep love or passion for Catherine. Try as he might, he has no power to leave her behind. Nelly also at times shows dislike for Catherine, yet she continues in her service for little other reason than to be able to convey the story to us years later, and because of her regard for the Lintons' employment when she is able to move to the Grange, which provides the opportunity for her to move upward in her position.

One of the reasons I believe we find it hard to pinpoint Catherine as a villain, other than her being overshadowed by Heathcliff, is because of her agency in constantly changing her identity. At any time in the novel, we are unable to label her as filling any one role; she repeatedly shifts into other manifestations of herself. This problem with identity boundaries is exemplified through the act of naming and the changing of her name. Lockwood is placed in Catherine's old bedroom when he finds he will not be able to make his way back to Thrushcross Grange because of a storm. He tries to lull himself to sleep by looking over the names etched on the windowsill: Catherine Earnshaw, Catherine Heathcliff, and Catherine Linton. Upon awakening, Lockwood remarks, "In vapid listlessness I leant my head against the window, and continued spelling over Catherine Earnshaw-Heathcliff-Linton, till my eyes closed; but they had not rested five minutes when a glare of white letters started from the dark, as vivid as spectresthe air swarmed with Catherines...” (20). Lockwood finds the name "obtrusive," an unwelcome disruption to his pending slumber. At this point, Lockwood is only envisioning the name floating in the air; there is no physical body associated with the name, which is the signifier, not the signified. Also notice here the plural use of "Catherines" in his conveyance of the scene, implying that she is more than one identity, although all names refer to one woman in one body. Obviously, it is not only Lockwood who distinguishes multiple Catherines, but Catherine herself, as she created the etchings, each one holding different significance. Later, her 
daughter will follow a similar pattern of changing identities. Going through the cycle, the first Catherine is Earnshaw, then Linton. Heathcliff does not become a surname, but we can insert her time with Heathcliff between the two identities or after her time as Catherine Linton, if we believe she is reunited with Heathcliff in the afterlife; the younger Cathy experiences almost a reversal of this naming, starting as Linton, then Heathcliff, and finally, with the promise of becoming an Earnshaw after the novel has ended. Both Catherines are never shown in their final state, and both Catherines use their multiple identities to elude blame and start with a clean slate, erasing any memories of villainy.

We see Catherine wield her power over Edgar just before she accepts his hand in marriage. Edgar is visiting Catherine at the Heights and is shocked at her behavior toward Nelly, when Catherine pinches Nelly and then lies about her malicious action, causing her to have a fit and violently shake Hareton, who is only a toddler at this point. Most importantly, Catherine strikes Edgar, who makes motions to leave her company, exclaiming, "You've made me afraid, and ashamed of you" (72). The scene quickly turns as Edgar becomes bewitched by her regardless of her despicable, turbulent behavior: “...he possessed the power to depart, as much as a cat possesses the power to leave a mouse half killed or a bird half eaten” (72-73). Only after this incident does Catherine agree to marriage, to wipe her behavior from Edgar's mind by continuing on as a Linton instead of as an Earnshaw. Her disregard for Heathcliff's feelings and her callous actions in this scene with Edgar align her with evil as sets deliberately to cause pain or bad/negative things to happen. Catherine's decision to marry Edgar arguably sets in motion all of Heathcliff's aggressive actions in the second portion of the novel, as Edgar is his main obstacle to being with Catherine.

Catherine carefully defines her self. Throughout the novel, there are an abundance of phrases beginning with "I am" or "Catherine is" but her most famous declaration of identity is her assertion that, "I am Heathcliff-he's always, always in my mind - not as a pleasure, any more than I am always a pleasure to myself-but, as my own being-”" (Bronte 82). Not only does Catherine define herself in terms of Heathcliff, but she also defines Heathcliff in terms of herself, explicitly excluding Edgar. She says, “...I’ve no more business to marry Edgar Linton than I have to be in heaven; and if the wicked man in there [Hindley] had not brought Heathcliff so low, I shouldn't have thought of it. It would degrade me to marry Heathcliff, now; so he shall never know how I love him; and that, not because he's handsome, Nelly, but because he's more myself than I am. Whatever our souls are made of, his and mine are the same, and Linton's is as different as a moonbeam from lightening, or frost from fire" (80-81, emphasis mine). One major problem with her definition of self is that we would have to understand Heathcliff in order to understand Catherine properly, and if we follow popular belief, pretty much all we know for sure is that Heathcliff is villainous. More 
importantly, Heathcliff is a completely mysterious character. Little is known about his history; he is named for a dead Earnshaw son, and his otherness keeps him from completely being accepted at The Heights until he is able to displace Hindley. Catherine's identity is directly tied up with Heathcliff's in her declaration, yet she forsakes herself, and her soul, and does marry Edgar because she is caught up in how others will perceive her rather than what her heart tells her she should do. Unfortunately for Heathcliff, he only overhears a portion of Catherine's speech - the portion where she claims that it would degrade her to marry him-which distorts his ideas about Catherine and becomes problematic as Heathcliff leaves Wuthering Heights to change himself.

While her elusive identities prevent Catherine from being named as villain, another problem with viewing Catherine as evil is her own inability to realize the impact of her actions. Heathcliff, in stark comparison, owns up to his villainy, laughing at the idea that Isabella can imagine him as the romantic hero:

Heathcliff...comments scornfully on the fact that his young bride Isabella had pictured him a hero of romance: so wildly deluded was this sheltered daughter of Thrushcross Grange, she expected chivalrous devotion to her and 'unlimited indulgences.' Heathcliff's mockery makes us aware of our own bookish expectations of him, for he is defiantly not a hero, and we are warned to avoid Isabella's error in 'forming a fabulous notion of my character.' Brontë's wit in this passage is supreme, for she allows her 'hero' to define himself in opposition to a gothic-romantic stereotype she suspects her readers (well into the twentieth century) cherish. And she allows him, by way of ridiculing poor masochistic Isabella, to ridicule such readers as well. (Oates 443)

Catherine, however, does not understand her role in the two households. She finds it only natural that others show great interest in her, and cannot understand when Nelly points out how the Lintons dote on her; in her mind, she is the one condescending to the whims of Isabella and Edgar. She may not be trying to manipulate the characters and their emotions, but she accomplishes just that nevertheless.

Upon her marriage to Edgar and her physical displacement from Wuthering Heights to Thrushcross Grange, Catherine exhibits "a double character without exactly intending to deceive anyone” (67). One conflict comes when she assumes she can bring her two worlds together, and that Edgar and Heathcliff will be friends simply because she wills it to be so, without considering the existing dynamics between the two. However, because of the setting and Catherine's narcis- 
sistic nature, she cannot foresee the situation as being destructive and does not even stop to consider the feelings of the men involved. Catherine's priorities must also be questioned: "When she announces that she means to marry Edgar without renouncing Heathcliff, Nelly says that she is either 'ignorant of the duties you undertake in marrying; or else, that you are a wicked, unprincipled girl'” (Stoneman 530). Nelly concludes by questioning Catherine's priorities and overall moral behavior. After all, Catherine is willing to marry Edgar despite the fact that she does not love him, as she sees the act of marriage as a social and economic maneuver.

Catherine's most destructive characteristic, however, is the hold she has over all men. Heathcliff is incomplete without her; Edgar cannot pull himself away from her; even Lockwood is enchanted by her. Returning to the example of Lockwood's “dream," in which Catherine has reached through the window, her spectre has a hold both on him and over him. He notes, “...finding it useless to attempt shaking the creature off...still it maintained its tenacious grip, almost maddening me with fear" (25). Even after he has cut her wrist on the glass and has gotten her to let go of him, he remains fixated on her and does not retreat or try to escape from the paneled bed. It is a fairly extreme reaction for him to be so drawn to her, even though at this point he has no idea of her history or her relationship to the inhabitants of the Heights whom he has met. If Catherine is shown as being this powerful to a stranger after her death, we can only imagine how bewitching she would appear during her lifetime. In an early instance of her control over men, she returns to Wuthering Heights after an extended stay at the Lintons because of an injury. Upon coming home, Heathcliff will not come out to greet her:

Cathy, catching a glimpse of her friend in his concealment, flew to embrace him; she bestowed seven or eight kisses on his cheek within the second, and, then, stopped, and drawing back, burst into a laugh, exclaiming. "Why, how very black and cross you look! and how-how funny and grim! But that's because I'm used to Edgar and Isabella Linton. Well; Heathcliff, have you forgotten me?” (54)

He refuses to move or even shake hands with Catherine, exclaiming, "'I shall not stand to be laughed at, I shall not bear it!' And he would have broken from the circle, but Miss Cathy seized him again” (54). As we can see, even though she is ridiculing Heathcliff and playing on his insecurities by comparing him to Edgar and deeming him inferior, Heathcliff is unable to escape from her. He verbally stands up to her, but physically he is drawn in over and over again.

Edgar obviously has no backbone in comparison to Heathcliff. Edgar's physi- 
cal descriptions make him sound small and feminine in comparison to the dark "wolfish" man who comes to own Wuthering Heights and, eventually, Thrushcross Grange. We first see the Linton children when they are young and after Brontë has established the world of the children at Wuthering Heights. Catherine and Heathcliff go exploring one evening to see how the Linton children pass their time, and Heathcliff poses a number of possibilities to Nelly when he returns, wondering if they "passed their Sunday evenings standing shivering" or "being catechised by their manservant, and set to learn a column of Scripture names, if they don't answer properly" to which Nelly replies, "They are good children, no doubt, and don't deserve the treatment you receive, for your bad conduct" (48). Nelly is already aligned with the Lintons here even before she has experienced how the Linton children actually behave. Heathcliff calls Nelly out on this idea by bursting her bubble of what her ideal children would be like: "And now, guess what your good children were doing? Isabella...lay screaming... shrieking as if witches were running red hot needles into her. Edgar stood on the hearth weeping silently, and in the middle of the table sat a little dog, shaking its paw and yelping, which, from their mutual accusations, we understood they had nearly pulled in two between them....we laughed outright at the petted things, we did despise them!” (48). Heathcliff's way of introducing the Linton children tells us that they are not perfect, nor are they morally good. They fight, they display greed, and cruelty of animals, and from Heathcliff's perception (and, initially, Catherine's), they are objects to be despised, not admired, emulated, or praised. Robin DeRosa writes, "From the moment Edgar and Isabella try to pull apart their dog, they figure as parodies - literal discursive copies of the original- of a more deadly sadomasochism exhibited by Catherine and Heathcliff” (DeRosa 42). The Lintons are passive beings, whereas Catherine and Heathcliff are active. Edgar and Isabella (and later the pathetic Linton) prefer to pass their time reading, where Catherine and Heathcliff (and later Cathy) spend time living in the world.

Edgar's behavior after Heathcliff's return is childish and petulant. Naturally he displays displeasure at Heathcliff's homecoming because he is aware of Catherine's affinity for the "gipsy" and this engenders feelings of insecurity for Edgar. Instead of responding in a stereotypically "masculine” way, Catherine describes Edgar as whiny: "Edgar is sulky, because I'm glad of a thing that does not interest him...I gave a few sentences of commendation to Heathcliff, and he, either for a head-ache or a pang of envy, began to cry: so I got up and left him” (98). Catherine sees his behavior as a "great weakness," which causes more tension in their relationship (98). "She is distressed at Edgar's lack of concern, and appalled to find out that he's reading despite her suicidal depression. 'Among his books!' she cries. 'And I dying! I on the brink of the grave!...What, in the name of all that feels, has he to do with books, when I am dying!'” (DeRosa 33). Catherine, of course, would be unhappy unless being lavished with attention, but she has al- 
ways known that Edgar was not the real object of her affections. Yet Edgar's passivity has just as much malicious intent as Heathcliff's active revengeful motions; while Heathcliff always gets right to the point, Edgar becomes nonconfrontational, and the absence of action when he should be showing concern speaks just as loudly to his ill intentions. Despite these differences in nature, Lintons and Earnshaws often find themselves in similar positions: "When Hindley's wife dies young, he dissipates himself in rowdy evenings of brandy and whist and sporadic violence. When Edgar's young wife also dies, he retreats from the world and languishes in his library, eventually, like Hindley, dying prematurely" (Williams 114). On a broader scale, one of the messages is that death is inevitable; we will all get to the same end regardless of the journey we take to get to that point. Brontë also sets up binaries between the Lintons and the Earnshaws (and Heathcliff) by using reading as a means of escape for some characters and exploration for others. Linking these ideas together, Cathy and Hareton give us hope that there is a balance to be found.

As Edgar demonstrates, the Lintons all have some sort of literary relationship which exhibits a form of escape from the world of the moors, causing tension between the characters who actually feel real experiences. The Lintons exhibit feelings of jealousy over never experiencing the "real" world, particularly when it comes to finding true love. This jealousy causes much of the tension between the two worlds. The events of the novel after Catherine's death approach reparation and mending what has become of the realms of Wuthering Heights and Thrushcross Grange. The second generation slowly bridges the two worlds together. Cathy is a combination of Earnshaw and Linton; she shows great affection for reading and is content being confined in the walls of the Grange for many years. In fact, "Her Eden is more conventional-a childhood spent in an enclosed garden...her mother's place of Eden and Paradise is a purgatory for the daughter. At the end, however, she anticipates a return to the Grange, her childhood home, regaining a paradise of domestic happiness" (Williams 116-17).

The hostile feelings between the two homes begin to melt away when we become more focused on the second generation of characters as Cathy becomes more acquainted with members of Wuthering Heights, despite her father's wishes for her to remain isolated. In this part of the story, we still see acts of evil, but we also see a mirroring of the first love triangle. The structure of the novel provides the opportunity for readers to predict the outcome by working in reverse to get Cathy and Hareton to match the idyllic state of Catherine and Heathcliff as they were in their youth. Heathcliff is responsible for orchestrating the actions of the younger characters in order to bring stability to the moors: "In order for reparation to occur, the thing that is lost must be duplicated or re-instituted. Therefore, Cathy, Linton, and Hareton must reenact the love triangle of the first generation comprised by Catherine, Edgar, Heathcliff” (Geerken 397-98). Significantly, we 
must note that the second generation's hereditary blood lines do not match up completely to the first generation; Cathy is a blend of Linton and Earnshaw, Linton is a blend of Heathcliff and Linton, and Hareton is an Earnshaw but highly influenced by Heathcliff in his upbringing. The natural hereditary traits of the characters of the first generation start to blend together and challenge the identity standards we think we have determined. For example, we think Linton is a weak, passive child, taking after his mother's side; later we see he is capable of tapping into his "Heathcliff" roots when he lets Heathcliff influence his decisions and trap Cathy in a thoroughly devious act. Once again, identity challenges our preconceived notions of villainy, as even a weak child can reveal dishonest and ill intentions.

Finally, to conclude the plot of the novel, we reach the point of reparation: Cathy falls in love with Hareton and accepts him - the act that her mother could not perform when she decides that to marry Heathcliff would be degrading. Heathcliff can die in peace, knowing that his acts of villainy have come to a close by reaching his goal; despite the treachery he instills in the novel, he is ultimately working toward assuring happiness in the afterlife by now feeling he has earned his right to be with Catherine. Hareton's desire to read takes a path of upward mobility and self-improvement, mirroring Heathcliff's self-improvement when he returns from his mysterious years abroad as a wealthy man. The impending union of Cathy and Hareton gives us hope that they have settled on their final identities and that they can now leave any acts of villainy behind as they embark on their new lives together.

In a world where there are only villains, one would expect chaos. Yet the characters of Wuthering Heights function together. There are tensions and boundaries, limits on spaces, and shifting identities, but somehow it all comes together to build a cohesive world teetering on the edge of stability. We keep returning to Emily Brontë's pages because we are interested in the fact that this world does not collapse in on itself despite the plots for revenge, the backstabbing, and the generally villainous actions exhibited by all characters. This same world also begins to shift to a hopeful place at the end, both through Cathy and Hareton's union and Catherine and Heathcliff's reunion in death. Readers who claim to have no sympathy for such villainous characters should check themselves after putting down the book, for do we not feel a pang of sadness at the idea of the doors of Wuthering Heights being shut up forever as the young couple moves to Thrushcross Grange? We pick up the book again and again to return there, to be "drunk" in the wilderness of it all.

\section{Notes}

${ }^{1}$ Like most scholars, I make the distinction here by calling the elder "Catherine" and the younger "Cathy," except where instances in the text differ. 
${ }^{2}$ For more information on speculative relationship dynamics between Catherine and Heathcliff, see: Marianne Thormählen, "The Lunatic and the Devil's Disciple: The 'Lovers' in Wuthering Heights," The Review of English Studies 48.190 (1997): 183-197; Eric Solomon, "The Incest Theme in Wuthering Heights," Nineteenth-Century Fiction, 14 (June 1959): 80-3; Dorothy Van Ghent, "The Window Figure and the Two-Children Figure in 'Wuthering Heights,"” Nineteenth-Century Fiction, 7 (Dec 1952): 189-197; and John Allen Stevenson, “'Heathcliff is Me!': Wuthering Heights and the Question of Likeness," Nineteenth-Century Literature, 43.1 (June 1988): 60-81.

${ }^{3}$ For a discussion on Heathcliff and the formation of identity in Gothic novels, see: Daniel Cottom, "I Think; Therefore, I Am Heathcliff." ELH 70.4 (Winter 2003): 1067-1088. For Heathcliff's vampiric (read: villainous) tendencies, see: James Twitchell, "Heathcliff As Vampire," Southern Humanities Review, 11 (1977): 355-62. For Heathcliff and otherness, see: Seven Vine, "The Wuther of the Other in Wuthering Heights," Nineteenth-Century Literature, 49.3 (Dec. 1994): 339-359, and Robin DeRosa, “'To Save the Life of the Novel': Sadomasochism and Representation in 'Wuthering Heights,"” Rocky Mountain Review of Language and Literature 52.1 (1998): 27-43.

${ }^{4}$ I would like to comment about the unavoidable topic of narration. In his article "The Villain in Wuthering Heights," James Hafley argues that Nelly Dean is the villain of the story because of her narration, and there are several occurrences where she acts villainous (e.g., by allowing Heathcliff to overhear Catherine, putting Heathcliff on the stairs his first night at the Heights). If Nelly is a villain, then it is likely that her narration would omit important factors. What then, could she be she hiding from us? She also displays greed through her desire to move up socially by associating herself with the Lintons and separating herself from the Earnshaws, although raised as a foster-sister to Hindley and Catherine. It is her early condemnations that set the tone for Heathcliff's later actions, and her word choices that attempt to pit the reader against him before he has actually committed any acts of villainy.

\section{Works Cited}

Brontë, Emily. Wuthering Heights. Ed. Pauline Nestor. London: Penguin, 2003. Print.

DeRosa, Robin. “'To Save the Life of the Novel': Sadomasochism and Representation in 'Wuthering Heights." Rocky Mountain Review of Language and Literature 52.1 (1998): 27-43. JSTOR. Web. 29 Mar. 2011

Geerken, Ingrid. "'The Dead Are Not Annihilated": Mortal Regret in Wuthering Heights." Journal of Narrative Theory 34.3 (2004): 373-406. JSTOR. Web. 29 Mar. 2011.

Hafley, James. "The Villain in Wuthering Heights." Nineteenth-Century Fiction 
13.3 (1958): 199-215. JSTOR. Web. 29 Mar. 2011.

Oates, Joyce Carol. "The Magnanimity of "Wuthering Heights"' Critical Inquiry 9.2 (1982): 435-49. JSTOR. Web. 29 Mar. 2011.

Stoneman, Patsy. "Catherine Earnshaw's Journey to Her Home among the Dead: Fresh Thoughts on Wuthering Heights and 'Epipsychidion"' The Review of English Studies 40.188 (1996): 521-33. JSTOR. Web. 29 Mar. 2011.

Thormählen, Marianne. "The Lunatic and the Devil's Disciple: The 'Lovers' in Wuthering Heights.” The Review of English Studies 48.190 (1997): 183-197. JSTOR. Web. 29 Mar. 2011

Williams, Anne. "Natural Supernaturalism in 'Wuthering Heights." Studies in Philology 82.1 (1985): 104-127. JSTOR. Web. 29 Mar. 2011 